\title{
Evaluating the Quality Of E-Courses from The Students Perception and E- course Quality Evaluation Metrics (DAU- EQEM) at Dar Al Uloom University
}

\author{
Mohammad Samir Abdel-Haq; Evan Asfoura \\ mohdsamir@dau.edu.sa; evan@dau.edu.sa. \\ Dar Al Uloom University \\ Kingdom of Saudi Arabia
}

Article History: Received: 10 November 2020; Revised 12 January 2021 Accepted: 27 January

2021; Published online: 5 April 2021

\begin{abstract}
E-learning and e-courses have received great practical and research interest during the previous years. Recently, there has been a growing interest in increasing efficiency and adherence to quality standards for e-learning and e-courses. With the restrictions imposed by the recent COVID-19 pandemic and the shift to reliance on e-learning and e-courses, this has increased the interest of higher education institutions, especially in the Kingdom of Saudi Arabia, Dar Al-Uloom University has developed a framework to ensure the quality of electronic and electronic learning courses DAU-EQEM The framework consists of eight standards, And that was applied through this study on 272 electronic courses distributed over three colleges in addition to the university preparation program at Dar Al Uloom University. To verify the evaluation results, the evaluation results were matched with the results of a survey of students' perception at the university about the quality of e-courses. The questionnaire consists of 5 themes and 25 items. The results showed a great convergence in the results of the evaluation tools used to verify the quality of electronic courses at Dar Al Uloom University. The results also showed an advanced level of quality of e-courses at Dar Al Uloom University, with the need to develop plans to ensure continuous improvement and raise the level of performance related to the e-learning system and its e-courses.
\end{abstract}

Keywords: E-learning, E-Courses, Quality Standards of E-learning.

\section{Introduction:}

E-learning includes all educational and interactive activities that individuals and groups deal with in a synchronized or asynchronous manner over the Internet or internal networks. [1]. E-learning includes all educational and interactive activities that individuals and groups deal with in a synchronized or asynchronous manner over the Internet or internal networks. E-learning changed learning patterns and strengthened self-learning and distance learning strategies. It also provided solutions that overcome obstacles and restrictions that may be imposed by some emergency circumstances to transcend the limits of time and space.

COVID-19 pandemic in 2020 had a major impact on all sectors and imposed restrictions on them calling for changing the way of business processes and patterns of communication between stakeholders. The education sector around the world is one of the most important sectors affected by this pandemic. E-learning and distance learning were the best alternative to ensure the continuity of the educational process, and as a result, there has been a significant increase in reliance on e-learning, e-courses and virtual classes. So, the need has increased more to apply standards that guarantee the quality of e-learning systems and e-courses.

Researchers in the higher education sector seek to participate in providing research contributions under the COVID-19 pandemic to serve the educational process and raise its level, and for this reason, this study aims to evaluate the quality of e-learning and e-course by two evaluation tools. The first tool is DAU-EQEM which is developed at DAU Dar Al Uloom University by Directorate of Quality and E-learning Department, which includes eight quality standards of e-learning system and e-courses. The second tool is the survey of student's Perception in all colleges of DAU on the quality of the e-learning system and e-courses. Both tools help to improve performance and provide an e-learning environment with high quality, which serves the learner and provides him with interactive electronic learning content that increases his motivation to learn.

\section{Research Background}

\subsection{Adoption of E-learming Systems Quality Standards}

Educational institutions that partially or completely rely on e-learning systems or provide the contents of academic courses electronically pay great attention to apply quality standards for e-learning to comply with these 
standards and ensure continuous improvement of e-learning system. This helps in providing a high-quality electronic learning environment that helps achieve student learning outcomes and improve their results, thus achieving high levels of satisfaction for the stakeholders benefiting from this educational institution [2]. Currently, educational and training institutions rely heavily on e-learning systems and rely on providing educational and training materials contents electronically or remotely. This has been accompanied by great interest by higher education institutions and researchers in applying quality standards for e-courses and e-learning systems to achieve better levels of performance. For example, The Commission of Institutions of Higher Education in the USA has developed a framework that includes five components to ensure the quality of e-learning, which are represented by 29 e-learning best practices which cover institutional context and commitment; curriculum and education; faculty support; student support and evaluation and assessment [3]. QM (Quality Matters Organization) is a well-known worldwide organization for quality assurance in online learning [4; 5] QM adopted sets of standards developed based on best practices in online courses to enhance student learning [4]. QM Rubric includes eight standards which is focus on general information for the course, learning objectives, course materials and assessment methods and the e-learning environment [6]. In 2015, the University of Illinois developed a framework for quality standards for online courses. This framework includes a set of standards divided into six main sections which cover instructional design and communication, student evaluation and assessment and learning resources support [7].

There are many studies that have developed frameworks and standards to ensure the quality of e-learning system and e-courses. Khan (2004) provided P3 model for the evaluation of three dimensions of e-learning, the People, Processes, and Product, the framework divide e-learning process into two major phases content development, and content delivery. P3 model is used to review the quality of products and services during the content development and content delivery phases of e-learning process. [8]. Masoumi and Lindstrom (2011) developed the e-learning quality framework based on 7 factors which cover institutional, technological, educational factors of e-learning and the provided support to learner and teaching staff support. Zhang \& Cheng (2012) developed PDPP model concentrates on fours aspects of quality: planning; development; process and product [9]. Hadullo and Omwenga's (2017) provided a framework for ensuring the quality of e-learning that included six factors which cover course development, learner support, institutional factors, and performance [10]. Table (1) summarizes the quality standards for e-learning and e-courses that were covered by previous related studies.

Table 1. Quality Standards for E-learning and E-courses

\begin{tabular}{|c|c|c|c|}
\hline No. & Research Title & Author(s) & E-learning Quality Standards \\
\hline 1 & $\begin{array}{l}\text { The Dimensions Of E-Learning } \\
\text { Quality: From the Learner's } \\
\text { Perspective. }\end{array}$ & Insung Jung (2011) & $\begin{array}{l}\text { Commission of Institutions of Higher } \\
\text { Education in the USA: } \\
\begin{array}{ll}1 . \quad \text { institutional context and } \\
\text { commitment } \quad \text { 2. curriculum and } \\
\text { instruction } 3 \text {. faculty support } 4 \text {. student } \\
\text { support 5. evaluation and assessment }\end{array}\end{array}$ \\
\hline 2 & $\begin{array}{l}\text { Going Online: Building Your } \\
\text { Business Law Course Using the } \\
\text { Quality Matters Rubric; } \\
\text { Student Perceptions of The } \\
\text { Impact of Quality Matters- } \\
\text { Certified Online Courses on } \\
\text { Their Learning and Engagement. }\end{array}$ & $\begin{array}{l}\text { Loafman, L., \& Altman, } \\
\text { B. W. (2014); } \\
\text { Sadaf, A., Martin, F., \& } \\
\text { Ahlgrim-Delzell, L. } \\
\text { (2019); } \\
\text { Quality Matters (2020) }\end{array}$ & $\begin{array}{l}\text { Quality Matters Organization: } \\
\text { 1. course overview and introduction } 2 . \\
\text { learning objectives (Competencies) } 3 . \\
\text { assessment and measurement } 4 . \\
\text { instructional materials 5. Learning } \\
\text { Activities and Learner Interaction } 6 . \\
\text { course technology } 7 \text {. learner support } 8 . \\
\text { accessibility and Usability }\end{array}$ \\
\hline 3 & $\begin{array}{l}\text { A Comprehensive Rubric for } \\
\text { Instructional Design in E- } \\
\text { Learning. }\end{array}$ & Debattista & $\begin{array}{l}\text { University of Illinois: } \\
\text { 1. Instructional design } 2 . \\
\text { Communication interaction and } \\
\text { collaboration } 3 \text {. Student evaluation and } \\
\text { assessment } 4 \text {. Learner support and } \\
\text { resources } 5 \text {. Web design } 6 \text {. Course } \\
\text { evaluation }\end{array}$ \\
\hline 4 & $\begin{array}{l}\text { Comprehensive Approach to } \\
\text { Program Evaluation in Open and }\end{array}$ & Khan (2004) & $\begin{array}{l}\text { P3 model: } \\
\text { the People, the Processes and the } \\
\text { Product. }\end{array}$ \\
\hline
\end{tabular}




\begin{tabular}{|l|l|l|l|}
\hline & $\begin{array}{l}\text { Distributed Learning } \\
\text { (CAPEODL) Model. }\end{array}$ & & \\
\hline 5 & $\begin{array}{l}\text { Quality In E-Learning: A } \\
\text { Framework for Promoting and } \\
\text { Assuring Quality in Virtual } \\
\text { Institutions. }\end{array}$ & $\begin{array}{l}\text { Masoumi } \\
\text { Lindstrom (2011) }\end{array}$ & $\begin{array}{l}\text { 1. Institutional Factor 2. Technological } \\
\text { Factor 3. Pedagogical Factor 4. } \\
\text { Evaluation Factor 5. Student Support 6. } \\
\text { Faculty Support 7. Instructional Design }\end{array}$ \\
\hline 6 & $\begin{array}{l}\text { Quality Assurance in E- } \\
\text { Learning: PDPP Evaluation } \\
\text { Model and Its Application. }\end{array}$ & Zhang \& Cheng (2012) & $\begin{array}{l}\text { PDPP model: } \\
\text { planning; development; process and } \\
\text { product. }\end{array}$ \\
\hline 7 & $\begin{array}{l}\text { A Model for Evaluating E- } \\
\text { Learning Systems Quality in } \\
\text { Higher Education in Developing } \\
\text { Countries. }\end{array}$ & $\begin{array}{l}\text { Hadullo } \\
\text { Omwenga's (2017) }\end{array}$ & $\begin{array}{l}\text { 1. Course Development 2. Learner } \\
\text { Support 3. Assessment 4. User } \\
\text { characteristics 5. Institutional factors 6. } \\
\text { Overall performance. }\end{array}$ \\
\hline
\end{tabular}

In kingdom of Saudi Arabia, the National elearning Center developed e-learning standards for higher education institutions consisted of two main sections, the first section: (Entity Standards) includes 27 sub-standards distributed into 3 standards: leadership, technology, qualification, and support. The second section (Program Standards) includes 39 sub-standards divided into four standards: design, interaction, fairness and accessibility, and measurement and evaluation [11].

\subsection{E-learning quality standards at Dar Al Uloom University}

Dar Al Uloom University (DAU) offers academic programs in bachelor's and master's degrees by six colleges, namely Business Administration, Law, Medicine, Dentistry, Architecture and Digital Design, College of Pharmacy and Applied Medical Sciences and the University Preparation Program (UPP). These programs are offered by face-to-face learning mode. For several years, DAU has provided the Electronic Learning Management System (DAU-LMS) as one of the learning resources that benefit students, and a web page is available for each course that includes electronic contents for learning, electronic assignments, and some electronic tests, and the DAU-LMS is used as one of the means of communication between the students and teaching staff.

Recently, with the primary reliance on e-learning during the COVID-19 pandemic, Dar Al Uloom University's interest in raising the quality of e-course content in the Learning Management System has increased. Therefore, the E-Learning Department and Directorate of Quality at Dar Al Uloom University has adopted a framework to ensure the quality of e-courses, this framework is based on good practices that have been mentioned in relevant previous studies, on the Quality Matters (QM) standards and on the standards the National elearning Center in KSA. Table (2) reviews the quality assurance standards applied in a university to verify the extent to which ecourses comply with these standards, each of these standards includes a set of practices related to the quality of elearning and e-courses.

Table 2. Quality Standards for E-learning and E-courses in Dar Al Uloom University

\begin{tabular}{|c|l|l|c|}
\hline \multicolumn{1}{|c|}{ Standard } & \multicolumn{1}{|c|}{ Description } & $\begin{array}{c}\text { No. of Good } \\
\text { Practices }\end{array}$ \\
\hline 1 & $\begin{array}{l}\text { Introduction and Overview } \\
\text { of the E- course. }\end{array}$ & $\begin{array}{l}\text { Clarifies the general design of the e-course for the learner } \\
\text { at the beginning of the semester. }\end{array}$ & 9 \\
\hline 2 & $\begin{array}{l}\text { Learning objectives and } \\
\text { outcomes }\end{array}$ & $\begin{array}{l}\text { Describes the learning objectives and outcomes that } \\
\text { learners will be able to do upon completion of the course } \\
\text { and relate them to the various course activities. }\end{array}$ & 5 \\
\hline 3 & $\begin{array}{l}\text { Evaluation } \\
\text { Measurement }\end{array}$ & $\begin{array}{l}\text { Describes the measurement and evaluation tools used to } \\
\text { assess the achievement of learning objectives and } \\
\text { outcomes by learners and provide feedback to them. }\end{array}$ & 5 \\
\hline 5 & $\begin{array}{l}\text { Lesign } \\
\text { Interaction }\end{array}$ & $\begin{array}{l}\text { Defines the specifications of educational materials that } \\
\text { enable learners to achieve the stated learning objectives } \\
\text { or outcomes. }\end{array}$ & 5 \\
\hline
\end{tabular}




\begin{tabular}{|c|l|l|l|}
\hline & & $\begin{array}{l}\text { electronic course and with the faculty member and the } \\
\text { extent of their integration with the educational activities } \\
\text { within the course. }\end{array}$ & \\
\hline 6 & $\begin{array}{l}\text { Technologies and } \\
\text { Techniques }\end{array}$ & $\begin{array}{l}\text { Specifies the techniques used in the course that assist } \\
\text { learners in achieving learning objectives and outcomes. }\end{array}$ & 4 \\
\hline 7 & $\begin{array}{l}\text { Learner and Teacher } \\
\text { Support }\end{array}$ & $\begin{array}{l}\text { Defines the specifications of the activities related to the } \\
\text { development and training of the faculty members and } \\
\text { learners to enable them to perform their tasks in the e- } \\
\text { learning environment. }\end{array}$ & 4 \\
\hline 8 & $\begin{array}{l}\text { Equity, Accessibility and } \\
\text { Usability }\end{array}$ & $\begin{array}{l}\text { Describes practices related to the ease of accessibility of } \\
\text { the e-course and the use of its contents, programs, tools } \\
\text { and learning resources, and the use of interaction and } \\
\text { communication tools. }\end{array}$ & 6 \\
\hline
\end{tabular}

The current study is concerned with studying the compliance of e-courses in Dar Al Uloom University, through the application of the framework used to ensure the quality of these courses and by surveying students' satisfaction on the quality of e-learning system and e-courses in all DAU colleges.

\section{Research Methodology}

This study is concerned with evaluating the compliance of e-courses at Dar Al Uloom University with the framework of the quality standards of e-courses and the e-learning system through an evaluation form designed to be compatible with these standards. To support the results of this evaluation, the study also depends on the survey of student's satisfaction in all colleges of DAU on the quality of the e-learning system and e-courses during the first semester of the academic year 2020-2021. Therefore, this study relies on the two methods to verify the quality of e-learning and e-courses at Dar Al Uloom University. The Research methodology aims to achieve the following research objectives:

- Determine the most important quality standards for e-learning and e-courses according to international and local best practices which adopted by Directorate of Quality at Dar Al Uloom University.

- Evaluate the compliance of electronic courses and the e-learning system with the quality standards adopted at Dar Al Uloom University.

- Surveying Student satisfaction at Dar Al Uloom University about the quality of e-learning and e-courses to validate the results of DAU-EQEM to help in developing improvement plans based on the results.

\subsection{E-course Quality Evaluation Metrics (DAU-EQEM)}

Depending on the framework of the quality standards of e-courses and e-learning at Dar Al-Uloom University, the Directorate of Quality and the E-Learning Department have developed the e-course quality evaluation metrics DAU-EQEM, after holding orientation workshops to define the quality standards of e-courses for all faculty members and quality officials at all colleges and giving the opportunity to all courses coordinators to make the necessary improvements to the contents of e-courses. The process of evaluating all e-courses at Dar Al Uloom University was implemented during the first semester 2020-2021. DAU-EQEM covers the eight quality standards which are mentioned above in Table (2). For each of these standards a set of practices, each practice is evaluated on four-point scale (1 to 4), (1) Unsatisfactory Performance, (2) Acceptable Performance, (3) Good Performance, (4) Excellent Performance. After evaluating each practice, the overall evaluation is calculated for each standard (Total scores of evaluating practices for the standard / number of practices for the standard), after evaluating all standards, the overall evaluation of the quality of the e-course is calculated (Total score for all standards evaluation / number of standards). Table (3) provides a sample of DAU-EQEM, Standard Two (Learning objectives and outcomes). Table (4) define the Quality Level of the Standard or E-course based on the evaluation results.

Table 3. provides a sample of DAU-EQEM, Standard Two (Learning objectives and outcomes)

\begin{tabular}{|c|c|c|c|c|c|}
\hline \multicolumn{6}{|c|}{ Standard Two (Learning Objectives and Outcomes) } \\
\hline \multirow{3}{*}{ No. } & \multirow{3}{*}{ Practices } & $(1)$ & $(2)$ & $(3)$ & $(4)$ \\
& & $\begin{array}{c}\text { Unsatisfactory } \\
\text { Performance }\end{array}$ & $\begin{array}{c}\text { Acceptable } \\
\text { Performance }\end{array}$ & $\begin{array}{c}\text { Good } \\
\text { Performance }\end{array}$ & $\begin{array}{c}\text { Excellent } \\
\text { Performance }\end{array}$ \\
\hline
\end{tabular}




\begin{tabular}{|c|c|c|c|c|}
\hline 2.1 & $\begin{array}{l}\text { The course learning objectives, or } \\
\text { learning outcomes are described } \\
\text { and are measurable. }\end{array}$ & & & $\checkmark$ \\
\hline 2.2 & $\begin{array}{l}\text { Unit-level learning objectives and } \\
\text { outcomes are described and } \\
\text { measurable and consistent with } \\
\text { course-level learning objectives } \\
\text { and outcomes. }\end{array}$ & & $\checkmark$ & \\
\hline 2.3 & $\begin{array}{l}\text { Learning objectives or outcomes } \\
\text { are stated clearly, are written } \\
\text { from the learner's perspective, } \\
\text { and are prominently located in the } \\
\text { e-course main page. }\end{array}$ & & $\checkmark$ & \\
\hline 2.4 & $\begin{array}{l}\text { The relationship between } \\
\text { learning objectives or outcomes } \\
\text { and learning activities is clearly } \\
\text { stated and are explained to the } \\
\text { students. }\end{array}$ & & $\checkmark$ & \\
\hline 2.5 & $\begin{array}{l}\text { The learning objectives or } \\
\text { outcomes are suited to the level of } \\
\text { the course. }\end{array}$ & & $\checkmark$ & \\
\hline & $\begin{array}{l}\text { The overall evaluation for the } \\
\text { standard }\end{array}$ & 3.2 / Good Performance & & \\
\hline
\end{tabular}

Table 4. Quality Level of the Standard or E-course based on the evaluation results

\begin{tabular}{|l|c|}
\hline \multicolumn{2}{|c|}{ Quality Level of Standard / E-course } \\
\hline Level & Average \\
\hline Excellent Performance & $\geq 3.5$ \\
\hline Good Performance & From 2.6 to $<3.4$ \\
\hline Acceptable Performance & From 2 to $<2.5$ \\
\hline Unsatisfactory Performance & From 1 to $<1.9$ \\
\hline
\end{tabular}

DAU-EQEM is applied on all e-courses of three colleges at DAU, namely, College of Business Administration (COB), College of Law (LAW), Architecture and Digital Design (CADD) and the University Preparation Program (UPP), Because all courses in these colleges are completely or highly dependent on DAU-LMS, e-learning and distance learning during the COVID-19 pandemic, for the medical colleges, they relied on several methods during the pandemic and relied on direct education due to the necessity for practical application of these courses in accordance with tight precautionary measures, so DAU-EQEM has not been applied to them, at least in the current period. Table (5) shows the results of the evaluation of e-courses for COB, LAW, CADD and UPP for the first semester of the academic year 2020-2021, depending on the application of DAU-EQEM.

Table 5. Results of the evaluation of e-courses for COB, LAW, CADD and UPP using DAU-EQEM

\begin{tabular}{|c|l|c|c|c|}
\hline No. & \multicolumn{1}{|c|}{ College } & $\begin{array}{c}\text { No. of } \\
\text { evaluated } \\
\text { E-courses }\end{array}$ & $\begin{array}{c}\text { overall evaluation of } \\
\text { the quality of the e- } \\
\text { course }\end{array}$ & Quality Level of E-courses \\
\hline 1 & University Preparation Program (UPP) & 29 & 3.5 & Excellent Performance \\
\hline 2 & Architecture and Digital Design (CADD) & 93 & 3.3 & Good Performance \\
\hline 3 & College of Business Administration (COB) & 148 & 3.2 & Good Performance \\
\hline 4 & College of Law (LAW) & 102 & 2.0 & Acceptable Performance \\
\hline
\end{tabular}

The evaluation results in Table (5) indicate that all e-courses at Dar Al Uloom University comply with the quality standards of e-courses, with the need for continuous improvement. The e-courses of UPP program 
achieved a high evaluation level (3.5 out of 4) corresponding to (Excellent Performance) this result reflects the high interest of the UPP program of e-courses quality, especially since most of the educational activities related to the course learning outcomes are carried out through the DAU-LMS. The e-courses at CADD and COB achieved a high level of quality reflecting the extent of the academic programs' interest in the quality of e-courses and their continuous follow-up and improvement compared to the large number of electronic courses offered, which amounted to (93) e-courses for CADD, (148) e-courses for COB, both colleges achieved Good Performance and results are very close to Excellent Performance, this calls for further improvement to achieve the highest level of quality of e-courses. Therefore, it is suggested that the CADD and COB review the quality of e-courses that negatively affected the evaluation result and work to raise the level of their quality. The College of Law has achieved an acceptable level of quality of e-courses, due to the nature of the educational environment in the college and the recent experience of relying on e-learning systems and e-courses, as the number of courses reached (102) courses based on traditional education and paper-based learning contents. Therefore, this level is considered a good start for the college and it needs an integrated improvement plan that covers all the quality standards of electronic courses at Dar Al Uloom University.

\subsection{Students' perception of the quality of electronic courses at Dar Al Uloom University}

To verify the reliability of the evaluation results for the quality of e-courses based on DAU-EQEM, and to survey students 'satisfaction with the quality of e-courses, a questionnaire was designed that includes 5 basic dimensions related to the quality standards of e-courses at Dar Al Uloom University and the total of 25 questionnaire items. Student satisfaction was measured on a five-level scale: (1) Strongly Disagree. (2) Disagree. (3) Neutral. (4) Agree. (5) Strongly Agree. The number of students who responded to the questionnaire was (355) students, distributed among the colleges, as shown in Table 6.

Table 6. The number of students responding to the questionnaire distributed according to the colleges

\begin{tabular}{|l|c|c|c|c|c|c|}
\hline \multicolumn{1}{|c|}{ Respondents } & COB & CADD & LAW & Medicine & Dentistry & UPP \\
\hline Number of respondents & 89 & 79 & 117 & 32 & 15 & 23 \\
\hline $\begin{array}{l}\text { The percentage of respondents } \\
\text { to the total number of responses }\end{array}$ & $25 \%$ & $22 \%$ & $33 \%$ & $9 \%$ & $4 \%$ & $7 \%$ \\
\hline
\end{tabular}

The responses of COB, CADD and LAW students reached (80\%) because these colleges completely or high level relying on e-courses and e-learning through COVID-19 Pandemic. The responses of UPP program reached (7\%) due to the small number of courses compared to other colleges. The low percentage of student responses in medical colleges because of relying on practical learning and the actual presence of students in these colleges, unlike other colleges. Table (7) presents the results of analyzing the dimensions of the questionnaire at the college and university level.

Table 7. The results of analyzing the students 'satisfaction survey on e-courses at Dar Al Uloom University

\begin{tabular}{|l|l|c|c|c|c|c|c|c|c|c|}
\hline \multicolumn{2}{|c|}{$\begin{array}{l}\text { Dimensions / } \\
\text { Items }\end{array}$} & $\begin{array}{c}\text { No. of } \\
\text { Surveyed } \\
\text { Items }\end{array}$ & COB & CADD & LAW & Medicine & Dentistry & UPP & DAU & \% \\
\hline $\begin{array}{l}\text { Thechnologies } \\
\text { Used in E- } \\
\text { Learning }\end{array}$ & 5 & 3.8 & 4.1 & 4.2 & 3.9 & 3.9 & 4.4 & $\mathbf{4 . 1}$ & $\mathbf{8 1 \%}$ \\
\hline D2 & $\begin{array}{l}\text { Designing of } \\
\text { E-Courses }\end{array}$ & 6 & 3.6 & 4 & 4 & 3.7 & 3.8 & 4.5 & $\mathbf{3 . 9}$ & $\mathbf{7 9 \%}$ \\
\hline D3 & $\begin{array}{l}\text { Interaction } \\
\text { Within E- } \\
\text { Courses }\end{array}$ & 4 & 3.6 & 3.9 & 4 & 3.4 & 3.8 & 4.4 & $\mathbf{3 . 9}$ & $\mathbf{7 7 \%}$ \\
\hline D4 & $\begin{array}{l}\text { Qualification } \\
\text { and Support }\end{array}$ & 5 & 3.6 & 4 & 4 & 3.3 & 3.7 & 4.5 & $\mathbf{3 . 9}$ & $\mathbf{7 7 \%}$ \\
\hline D5 & $\begin{array}{l}\text { Evaluation } \\
\text { and } \\
\text { Measurement }\end{array}$ & 4 & 3.5 & 3.9 & 4 & 3.1 & 3.3 & 4.5 & $\mathbf{3 . 7}$ & $\mathbf{7 4 \%}$ \\
\hline \multicolumn{1}{|c|}{ Overall Satisfaction } & $\begin{array}{c}3.6 \\
(72 \%)\end{array}$ & $\begin{array}{l}4 \\
(80 \%)\end{array}$ & $\begin{array}{c}(80 \%) \\
(70 \%)\end{array}$ & $\begin{array}{c}(74 \%) \\
(90 \%)\end{array}$ & $\mathbf{3 . 9}$ & $\mathbf{7 8 \%}$ \\
\hline
\end{tabular}


The overall satisfaction of students on the quality of the e-courses at Dar Al Uloom University was 78\%, which is considered a good level and calls for the development of improvement plans. The first dimension related to " The Technologies Used in E-Learning" achieved a rate of $(81 \%)$ of student satisfaction, which is the highest rate, and the fifth dimension related to "Evaluation and Measurement " achieved (74\%) of student satisfaction, which is the lowest percentage. The results of the colleges' evaluation reflect a very good level of student satisfaction levels for all colleges, where the evaluation rates ranged between $(70 \%$ to $80 \%)$, while the university preparation program (UPP) achieved an advanced level of student satisfaction levels that reached (90\%), the results show that all dimensions needs to be reviewed to develop continuous improvement plans for the quality requirements of ecourses and e-learning at Dar Al Uloom University, specifically dimension No.5 " Evaluation and Measurement ".

\section{Discussion}

The purpose of this study was to evaluate the Quality Of E-Courses by applying E-course Quality Evaluation Metrics (DAU-EQEM) at Dar Al Uloom University, and verifying the results through students 'perception of the quality of e-courses and e-learning at Dar Al Uloom University. The evaluation of standards was applied to the ecourses of three colleges COB, LAW, and UPP. Table 8 presents the final evaluation results of the evaluation tools used in this study.

Table 8. the final evaluation results of e-courses at Dar Al Uloom University

\begin{tabular}{|l|c|c|c|}
\hline Colleges / Evaluation Tools & DAU-EQEM & $\begin{array}{c}\text { students 'satisfaction on } \\
\text { e-courses }\end{array}$ & Difference \\
\hline UPP & $3.5(88 \%)$ & $4.5(90 \%)$ & $(+) 2 \%$ \\
\hline CADD & $3.3(82 \%)$ & $4(80 \%)$ & $(-) 2 \%$ \\
\hline COB & $3.2(80 \%)$ & $3.6(72 \%)$ & $(-) 8 \%$ \\
\hline LAW & $2.0(50 \%)$ & $4(80 \%)$ & $(+) 30 \%$ \\
\hline
\end{tabular}

Comparison of evaluation results in Table 8 shows that the difference in the evaluation amounted to (2\%) only in UPP and CADD, and (8\%) in COB, this reflects the credibility of the evaluation result of the evaluation tools used in evaluating UPP, CADD and COB. Comparing the evaluation results shows that there is a big difference between the results of the assessment tools used to evaluate e-courses in LAW. Where the result of DAU-EQEM was (50\%), but the level of student satisfaction with the quality of e-courses in LAW achieved (80\%), this reflects an advanced level of satisfaction from the perception of students. Since the number of students participating in the evaluation of the quality of e-courses in LAW is (117) students, which is the largest number compared to the other colleges with a participation rate $(33 \%)$ of the size of the participating sample, this means that LAW provides high quality of e-courses, especially regarding interaction with Students, technologies used in e-Learning, and assessment methods. The reason for the low evaluation result using DAU-EQEM may be attributed to the fact that the evaluation criteria on which this tool relies is not well suited to the nature of academic programs, learning content and teaching strategies in LAW. This calls for reviewing the evaluation criteria applied on e-course on LAW to find out the reasons for the low in the evaluation and developing improvement plans for the evaluation system, and also, the improvement plans for the e-courses of LAW.

\section{Conclusion}

This study aimed to evaluate the quality of e-course and e-learning at Dar Al Uloom University DAU by using DAU-EQEM which is an evaluation framework developed in DAU. DAU-EQEM is based on national, international, and good practices of e-course quality standards. The results indicated that there is an advanced level in UPP, a very good level COB and CADD, and an acceptable level in LAW in terms of commitment to the quality of electronic courses. To verify the evaluation results, the students 'opinion was surveyed about the quality of the e-courses, and the survey results were close to the results of DAU-EQEM. However, there is a difference in the evaluation results between the evaluation tools used in LAW. Accordingly, the study presented improvement proposals, including the development of a comprehensive plan at the University level and all colleges to raise the level of quality of e-courses in all colleges to reach the mastered level of quality.

\section{Acknowledgement}

The researchers extend their thanks and gratitude to the Deanship of Graduate Studies and Scientific Research at Dar Al Uloom University for their support and funding of this study. 


\section{References}

[1]. Sangra, Vlachopoulos, and Cabrera (2012). Building an Inclusive Definition of E-Learning: An Approach to the Conceptual Framework. The International Review of Research in Open and Distance Learning. Vol 13 | No 2. April 2012.

[2]. Schreurs and Al-Huneidi (2012). e-Learning Self-Assessment Model (e-LSA). ICELW. The International Conference on E-Learning in the Workplace Conference Proceedings. June 13th-15th, New York, NY, USA.

[3]. Insung Jung (2010). The dimensions of e-learning quality: from the learner's perspective. Education Tech Research Dev (2011) 59:445-464 DOI 10.1007/s11423-010-9171-4

[4]. Sadaf, A., Martin, F., \& Ahlgrim-Delzell, L. (2019). Student perceptions of the impact of quality matters-certified online courses on their learning and engagement. Online Learning, 23(4), 214-233. doi:10.24059/olj.v23i4.2009

[5]. Loafman, L., \& Altman, B. W. (2014). Going online: Building your business law course using the Quality Matters Rubric. Journal of Legal Studies Education, 31(1), 21-54.

[6]. Quality Matters (2020), available at https://www.qualitymatters.org/qa-resources/rubric-standards/higher-ed-rubric. Accessed 24-06-2020

[7]. Martin Debattista (2018). A comprehensive rubric for instructional design in e-learning. The International Journal of Information and Learning Technology Vol. 35 No. 2, 2018 pp. 93-104 Emerald Publishing Limited 2056-4880 DOI 10.1108/IJILT-09-2017-0092.

[8]. Khan, B.H. (2004). Comprehensive approach to program evaluation in open and distributed learning (CAPEODL) model. Introduced in the Program Evaluation course. George Washington University.

[9]. Zhang \& Cheng (2012). Quality Assurance in E-Learning: PDPP Evaluation Model and its Application. The International Review of Research in Open and Distance Learning. Vol 13 | No 3. April 2012.

[10]. Hadullo, Oboko, Omwenga (2017). A model for evaluating e-learning systems quality in higher education in developing countries. International Journal of Education and Development using Information and Communication Technology (IJEDICT), 2017, Vol. 13, Issue 2, pp. 185-204.

[11]. National elearning Center, KSA (2020). National Standards of E-learning. available at https://nelc.gov.sa/en/standards. Accessed 01-09-2020. 